Journal of Advanced College of Engineering and Management, Vol. 5, 2019

\title{
OPTIMIZATION OF STANDALONE PHOTOVOLTAIC SYSTEM CONSIDERING LOSS OF POWER SUPPLY PROBABILITY FOR REPEATER STATION OF NEPAL TELECOM
}

\author{
Krishna Ranjit ${ }^{1}$, Dr. Sanjeev Maharjan ${ }^{2}$ \\ ${ }^{1,2}$ Department of Mechanical Engineering, Pulchowk Campus, Institute of Engineering, T.U., Nepal \\ Email Address: krishnaranjit@gmail.com
}

\begin{abstract}
Telecommunication plays the vital role in the human life and has become an integrated part of the society. The rapidly growing information and communications technology and increasing competition in telecommunication markets triggers the telecom operators to extend their networks and services to their potential customers in different geographical locations. It necessitates them to install repeaters and communication towers powered by standalone Photovoltaic system in remote rural areas. This paper presents optimization of standalone photovoltaic system maximizing reliability in one of such remotely located Palethar Repeater Station of Nepal Telecom situated in Dadeldhura district of Far-western region. The optimization is carried out using Genetic Algorithm in MATLAB software for given load profile enhancing reliability of the system with maximum reduction of overall system cost. The loss of power supply probability (LPSP) is considered for reflecting the reliability of the system. The paper discusses different optimal configuration of standalone PV system under various values of LPSP after optimization.
\end{abstract}

Keywords: LPSP, Standalone Photovoltaic, GA, optimization, LCOE

\section{Background}

In Telecommunication sector, Telecom Operators are always looking for increasing the coverage area of their networks and services to their potential customers to extend their business, thus they also install Repeaters and BTS Towers in remote rural areas where there is lack of central grid electricity connection and transportation difficulties which highlights a potential barrier to Telecommunication industry growth [1]. Standalone photovoltaic system is a reliable power source and an economically viable solution for remote telecommunication station [2].

Proper design of standalone renewable energy power systems is a challenging task, as the coordination among renewable energy resources, energy storages and loads is very complicated. Generally the main objectives of the optimization design are power reliability and cost [3]. Reasonable sizing of such power systems could improve the power supply reliability and reduce the annual system cost [4]. Stand-alone systems can be more cost effective and reliable if they are optimally designed. [5].In the sizing design optimization, there are a lot of variables and parameters that have to be considered. Therefore, the sizing of the system is much more complicated and consists of economic objectives. The algorithm having strength of global optimum with meta-heuristic approach such as Genetic Algorithm should be used to find the intended solutions[6].

\section{Introduction to Repeater station of Telecommunication}

A repeater is an automated radio station that extends the range of communications consisting of a receiver tuned to one frequency and a transmitter tuned to a different frequency, linked together [7]. Repeaters improve communication coverage in systems using frequencies that typically have line-ofsight propagation and allow stations that are out of each other's line-of-sight range to communicate reliably[8]. Province 7 is coterminous with the former Far-Western Development Region, Nepal[9]. 
The repeater stations that are remotely located in hilly and mountainous part of Far-western region are primarily powered by Standalone Photovoltaic System [10].

\subsection{Standalone Photovoltaic System of Nepal Telecom}

The typical Standalone Photovoltaic System of Nepal Telecom consists of PV arrays, Battery banks, charge controllers and Load distribution board and controller. The Figure 2.1 given below depicts the typical Standalone PV system used in remote Telecommunication sector of Nepal Telecom.

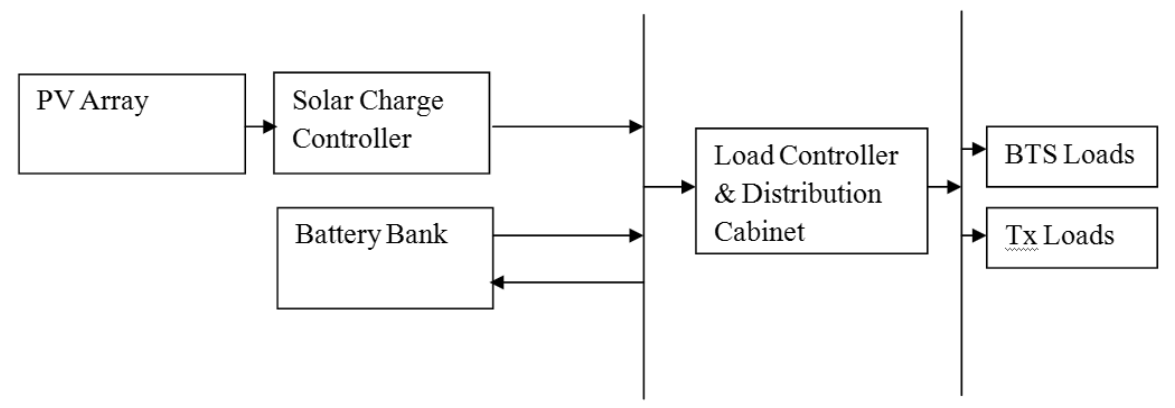

Figure 1: Block Diagram of Typical Standalone PV system of Nepal Telecom

\subsection{Case Study of Palethar Station}

The chosen remote station for case-study i.e. Palethar Repeater (Latitude: $29^{\circ} 22^{\prime} 17.47^{\prime \prime} \mathrm{N}$, Longitude: $80^{\circ} 38^{\prime} 4.14 " \mathrm{E}$, Altitude:1943metres) possesses the total installed capacity of $3.06 \mathrm{~kW}$ of PV system accompanied by battery bank of 500AH. The Repeater and Base Trans receiver Station (BTS) Tower of Nepal Telecom (NT) site has CDMA BTS and Microwave as transmission medium. The total power consumption by the BTS and Microwave Transmission are as shown in table 2.1.

Table 1: Load data of Palethar Repeater/BTS of Nepal Telecom

\begin{tabular}{|l|l|l|c|}
\hline S.N. & BTS Load & Transmission Load & Total Load \\
\hline 1 & $750 \mathrm{~W}$ & $125 \mathrm{~W}$ & 875 \\
\hline
\end{tabular}

\section{Previous works on Optimization of Standalone Photovoltaic system}

The DIRECT (DIviding RECTangles) optimal sizing methodology which is an effective deterministic algorithm to find the global optimum presented by Belfikra [11], outputs the optimal PV system, ensuring that the system total cost is minimized subject to the constraints. A detailed analysis of the different types of cost (capital cost, installation cost, annualized operation and maintenance cost, replacement cost) for each component of the PV/wind/battery/diesel power system was presented for the 20 years system lifetime[12]. However, classical algorithms could not obtain the global optimal solution within a reasonable amount of time. In the last few decades, new generation artificial algorithms, like GA and PSO, were widely used because they required less computation time and had better accuracy[4].

Firefly Algorithm was used to optimally select the Standalone Photovoltaic system components. The results showed that Firefly Algorithm-based Sizing Algorithm is capable of determining the optimal solutions. The algorithm was incorporated into sizing algorithm with the technical performance indicator was set to optimize the Loss of Power Supply Probability (LPSP)[13]. The paper presented by Awale et al. (2015)showed the reliability analysis of standalone hybrid power system for Remote 
Telecom CDMA BTS of Nepal Telecom in Okhaldhunga Site. In this paper, probabilistic approach of reliability evaluation using Monte Carlo Simulation is applied for the reliability evaluation. The HOMER uses an enumerative method to obtain the optimal design by evaluating all the possible solutions. However, when the number of possible design points is very high, the enumerative method requires excessively high calculation time. Thus, heuristic techniques, such as the evolutionary algorithms, were recommended to solve these kinds of optimization problems[14].

Based on literature review, there is need of metaheuristic stochastic methodology for optimization of standalone PV system considering loss of Power Supply Probability minimizing overall system costs.

Since, Genetic Algorithm is one of the nature-inspired metaheuristic stochastic global search algorithm, hence this methodology is used for the given optimization problem of Standalone PV system for remote telecommunication application in context of Nepal with consideration of reliability of power supply.

\section{Solar Energy Model}

\subsection{Hourly Global Solar Radiation on the horizontal surface}

The Angstrom regression equation related monthly average daily radiation based on extraterrestrial radiation is given by equation (4.1)[15].

$\bar{H}=\overline{H_{0}}\left(a+b \frac{\bar{n}}{\bar{N}}\right)$.

where, $\bar{H}$ is the monthly average daily radiation on the horizontal surface, $\overline{H_{0}}$ is the monthly average daily extraterrestrial solar radiationa, $\mathrm{b}$ are empirical coefficients, $\mathrm{n}$ is the monthly mean daily sunshine duration, $\bar{N}$ is the monthly mean maximum possible sunshine duration.

The hourly total solar radiation on the horizontal surface can be calculated by equation[16] (4.2).

$G=\frac{\pi H}{24}\left(0.409+0.5016 \sin \left(\omega_{s}-60\right)+\left(0.6609-0.4767 \sin \left(\omega_{s}-60\right)\right) \cos \omega\right) \frac{\cos \omega-\cos \omega_{s}}{\sin \omega_{s}-\left(\frac{2 \pi \omega_{s}}{360}\right) \cos \omega_{s}} .$.

where, $\omega$ is the hour angle in degrees for time (i.e., the midpoint of the hour for which the calculation is made)

\subsection{Temperature Modeling}

The temperature during sunrise time to $3 \mathrm{PM}$ is given by equation (4.3)[17].

$T_{t}=T_{\text {ave }_{0}}-\left(\frac{\Delta T}{2}\right) \cos \left[\frac{\pi\left(t-t_{r}\right)}{\left(15-t_{r}\right)}\right]$.

where, $T_{t}=$ temperature at time $\mathrm{t}\left[{ }^{0} \mathrm{C}\right]$

$T_{\text {ave }_{0}}=$ average morning temperature $=\left(\mathrm{T}_{\min }+\mathrm{T}_{\max }\right) / 2$

$\Delta T=$ Diurnal temperature $=\left(T_{\max }-T_{\min }\right)$

$t_{r}=$ time of sunrise, Hour of maximum temperature occourance $=3 \mathrm{PM}$

The temperature from 3PM to midnight is given by equation (4.4).

$T_{t}=T_{\text {ave }_{1}}+\left(\frac{\Delta T^{\prime}}{2}\right) \cos \left[\frac{\pi(t-15)}{\left(t_{r}{ }^{\prime}+9\right)}\right]$.

where, $T_{t}=$ temperature at time $\mathrm{t}\left[{ }^{0} \mathrm{C}\right]$

$T_{\text {ave }}=$ average morning temperature $=\left(\mathrm{T}_{\max }+\mathrm{T}_{\min 1}\right) / 2$

$\Delta T^{\prime}=$ Evening temperature drop $=\left(\mathrm{T}_{\max }-\mathrm{T}_{\min 1}\right)$

$t_{r}{ }^{\prime}=$ time of sunrise on next day

The temperature from mid-night to sunrise the next day is given by equation (4.5).

$T_{t}=T_{a v e_{1}}+\left(\frac{\Delta T^{\prime}}{2}\right) \cos \left[\frac{\pi(t+9)}{\left(t_{r}{ }^{\prime}+9\right)}\right] \ldots$ 


\subsection{Modeling of PV Panel}

The model presented by Belfkira[11] allows calculating the PV panel current (Impp) and voltage (Vmpp) at the maximum power point using a maximum power point tracker (MPPT). This model includes the effects of irradiation level and panel temperature on the output power as follows:

$I_{m p p}=I_{S C} \cdot\left\{1-C_{1}\left[\exp \left(\frac{V_{\max }}{C_{2} \cdot V_{o c}}\right)-1\right]\right\}+\Delta I$

$V_{\text {mpp }}=V_{\text {max }}+\mu_{V, o c} \cdot \Delta T$

and the PV panel power at the maximum power point, $\mathrm{P}_{\mathrm{mpp}}$, is expressed as:

$\mathrm{P}_{\mathrm{mpp}}=\mathrm{V}_{\mathrm{mpp}} \cdot \mathrm{I}_{\mathrm{mpp}}$

with,

$C_{1}=\left(1-\frac{I_{\max }}{I_{S C}}\right) \cdot \exp \left(-\frac{V_{\max }}{C_{2} \cdot V_{O C}}\right)$

$C_{2}=\left(\frac{V_{\max }}{V_{O C}}-1\right) \cdot\left[\ln \left(1-\frac{I_{\max }}{I_{S C}}\right)\right]^{-1}$

$\Delta I=I_{S C} \cdot\left(\frac{G_{T}}{G_{r e f}}-1\right)+\mu_{I, S C} \cdot \Delta T$.

$\Delta T=T_{c}-T_{c, r e f}$

$\mathrm{T}_{\mathrm{c}}$ can be expressed as follows:

$T_{c}=T_{a}+\frac{N O C T-20}{800} \cdot G_{T}$.

where, $I_{\operatorname{mpp}} \& I_{\max }=$ panel current at the maximum power point\& reference point,

$I_{S C}=$ Short-circuit current, $V_{O C}=$ Open-circuit voltage,

$V_{\text {mpp }} \& V_{\max }=$ maximum voltage at maximum power point $\&$ reference point,

$G_{T}=$ Hourly global solar radiation on the tilted surface,

\section{Battery Energy Model}

For the charging process and discharging process of the battery bank, the state of charge (SOC) can be calculated from the following equation[11]:

$\operatorname{SOC}(t+\Delta t)=\operatorname{SOC}(t)+\eta_{\text {bat }}\left(\left(P_{B}(t)\right) / V_{\text {bus }}\right) \Delta t$.

where $\eta_{\text {bat }}$ is equal to the round-trip efficiency, $V_{\text {bus }}$ is the DC bus voltage $(\mathrm{V})$

and $\Delta \mathrm{t}$ is the hourly time step is set equal to $1 \mathrm{~h}$

The lower limit that the state of charge of the battery bank cannot exceed at the time of discharging $\left(\mathrm{SOC}_{\min }\right)$ may be expressed as follows:

$\mathrm{SOC}_{\min }=(1-\mathrm{DOD}) \cdot \mathrm{SOC}_{\max }$

\section{Loss of Power Supply Probability}

The Loss of Power Supply Probability (LPSP), which is defined in terms of the SOC, is the power reliability index of a system. LPSP can be defined as the long-term average fraction of the load that is not supplied by the standalone power system.

The LPSP can be defined as:

$\mathbf{L P S P}=\frac{\sum_{t}^{T} L P S(t)}{\sum_{t}^{T} P_{L}(t)}$

where, LPS is loss of power supply at time $t$ given by following equations:

$$
\begin{array}{cc}
\operatorname{LPS}(\mathrm{t})=0 & \text { for } \Delta \mathrm{P}(\mathrm{t}) \geq 0, \\
& \Delta \mathrm{P}<0 \& \operatorname{SOC}(\mathrm{t}) \geq \mathrm{SOC}_{\min }(\mathrm{t}) \ldots \\
\operatorname{LPS}(\mathrm{t})=P_{L}(t) & \text { for } \Delta \mathrm{P}(\mathrm{t})<0 \& \mathrm{SOC}(\mathrm{t}) \leq \mathrm{SOC}_{\min }(\mathrm{t}) \ldots \ldots
\end{array}
$$

where, $\mathrm{P}_{\mathrm{L}}$ is the power demand 


\section{Research Methodology}

For the given research work, the objective function and its constraints are firstly defined. The data of the site is then collected from different sources. After that simulation of hourly temperature profile and hourly solar radiation on tilted surface of the given site is performed along with calculation of hourly PV Power delivered by each type of solar panels at maximum point. Finally, Optimization is carried out using Genetic Algorithm to achieve the optimal solution. Finally, the results obtained under various scenarios are discussed.The four different models of solar panels and four different models of battery with their technical and economic parameters are considered. These models are generally in use for Telecommunication purposes.

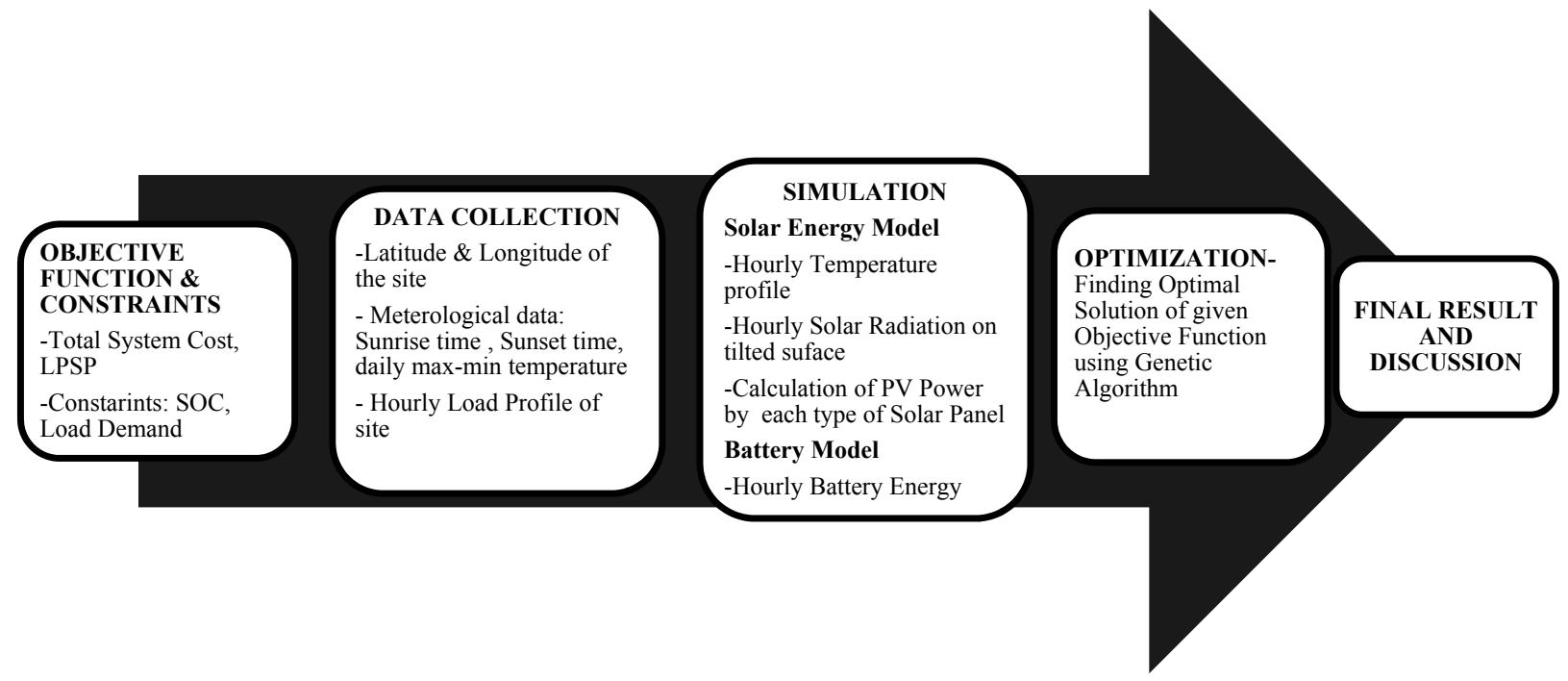

Figure 2: Flow Chart of Research work

\subsection{Objective Function and constraints}

The objective function is the system total cost which is equal to the sum of total capital cost, installation cost and maintenance cost of each type of PV and battery as follows:

$\mathrm{TC}(\mathrm{x})=\min \left\{\mathrm{C}_{\mathrm{C}}(\mathrm{x})+\mathrm{C}_{\mathrm{M}}(\mathrm{x})+\mathrm{C}_{\mathrm{I}}(\mathrm{x})\right\}$

where, $\mathrm{TC}=$ Total Cost $; \mathrm{x}$ is variable defined as $\left\{\mathrm{N}_{\mathrm{PV}, \mathrm{p}}^{\mathrm{i}}, \mathrm{N}^{\mathrm{k}}{ }_{\mathrm{BAT}, \mathrm{p}}\right\}$;

$\mathrm{C}_{\mathrm{C}}=$ Sum of total capital cost, $\mathrm{C}_{\mathrm{M}}=$ Sum of total maintenance cost, \& $\mathrm{C}_{\mathrm{I}}=$ Sum of total installation

cost,

The minimization of the objective function is subject to following constraints:

$\mathrm{P}_{\mathrm{P}}=\mathrm{P}_{\mathrm{L}}$

$\mathrm{SOC}_{\min } \leq \mathrm{SOC} \leq \mathrm{SOC}_{\max }$

Where, $\mathrm{P}_{\mathrm{P}}$ is the power produced by the system, it is calculated as follows:

$\mathrm{P}_{\mathrm{P}}=\mathrm{P}_{\mathrm{RE}}-\mathrm{P}_{\mathrm{B}}$

where $\mathrm{P}_{\mathrm{RE}}$ is the power produced by the renewable resources as follows:

$P_{R E}=\sum_{i=1}^{n_{P V}} N_{P V}^{i} \cdot P_{m p p}^{i}$

where $\mathrm{P}_{\text {mpp }}^{\mathrm{i}}$ the power at the maximum power point of the PV panel of type $i$ type, $\mathrm{n}_{\mathrm{PV}}=4$ is total number of $\mathrm{PV}$ panel types and $\mathrm{N}_{\mathrm{PV}}^{\mathrm{i}}=\mathrm{N}_{\mathrm{PV}, \mathrm{p}}^{\mathrm{i}} \mathrm{X} \mathrm{N}^{\mathrm{i}}{ }_{\mathrm{PV}, \mathrm{s}}$ is the total number of $\mathrm{PV}$ panels of type $\mathrm{i}$. $\mathrm{P}_{\mathrm{B}}$ is the input/output power of the battery bank, $\mathrm{P}_{\mathrm{B}}>0$ during the charging process of the battery and $\mathrm{P}_{\mathrm{B}}<0$ in the discharging process.Therefore, the model of the sizing optimization of the standalone PV system is expressed as follows:

Minimize:

$\mathrm{TC}(\mathrm{x})=\min \left\{\mathrm{C}_{\mathrm{C}}(\mathrm{x})+\mathrm{C}_{\mathrm{M}}(\mathrm{x})+\mathrm{C}_{\mathrm{I}}(\mathrm{x})\right\}$

Subjected to 
$\mathrm{SOC}_{\min }(\mathrm{t}) \leq \mathrm{SOC}(\mathrm{t}) \leq \mathrm{SOC}_{\max }(\mathrm{t})$

$\mathrm{P}_{\mathrm{p}}(\mathrm{t})=\mathrm{P}_{\mathrm{L}}(\mathrm{t})$

LPSP $\leq$ LPSP $_{\text {set }}$

\section{Results and Discussion}

Simulation of hourly solar radiation on tilted surface of Dadeldhura is performed in MATLAB after encoding them. The duration of simulation is set to be 8760 hours and the time step of the simulation is one hour. Meanwhile, the simulation of hourly temperature variation with duration of 8760 hours taking the time step one hour is performed. The hourly solar radiation and temperature are used to compute the hourly power generated by the PV panels under consideration. Finally, the GA optimization function is used to get result of optimization under various scenarios of reliability of the system.

\subsection{Simulation Results}

The MATLAB simulation result of hourly solar radiation on the tilted surface and hourly temperature variation are shown in the Figure 8.1 and Figure 8.2 below.

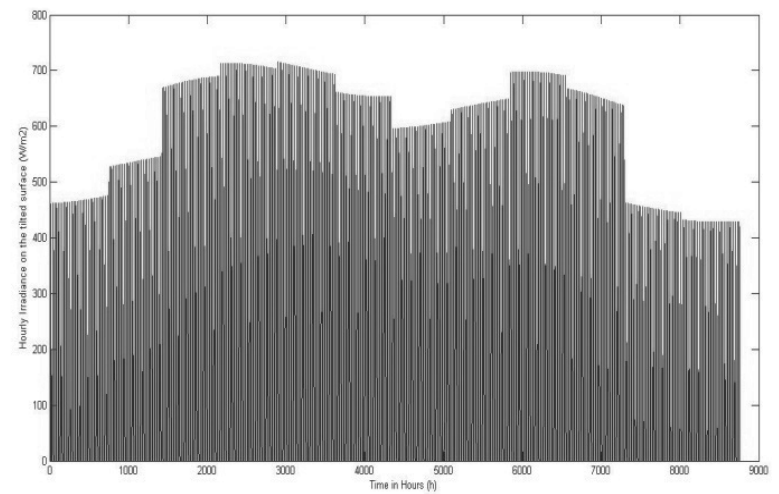

Figure 3: Simulation result of hourly Solar Radiation on the tilted surface

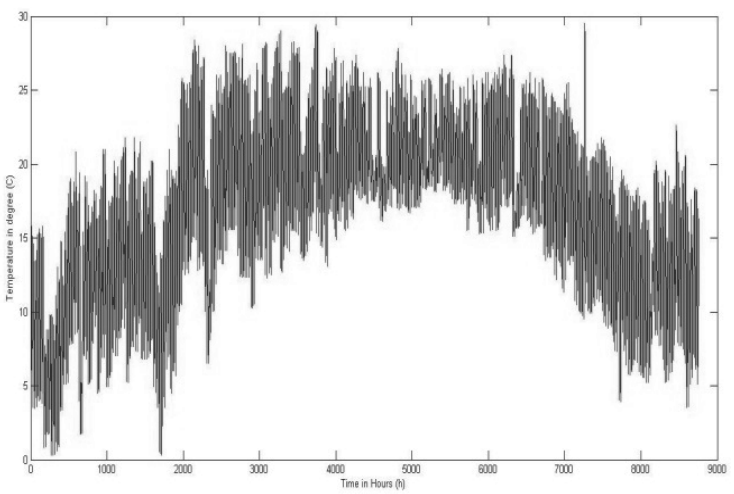

Figure 4: Simulation result of hourly temperature variation

\subsection{Summary of Optimization result under different LPSP}

The Optimization is carried out under different LPSP. The obtained results can be summarized as shown in Table 8.1 below:

Table 2: Summary of Optimization result under various LPSP

\begin{tabular}{|c|c|c|c|c|c|c|}
\hline S.N. & LPSP & Output Combination & Total Cost & $\begin{array}{c}\text { Annual } \\
\text { Energy (in }\end{array}$ & $\begin{array}{c}\text { Plant } \\
\text { Capacity }\end{array}$ & LCOE \\
\hline 1 & 0 & {$\left[\begin{array}{llllllll}6 & 2 & 4 & 9 & 0 & 1 & 0 & 0\end{array}\right]$} & $52,055.15$ & 11313.90 & 8.76 & 23.00 \\
\hline 2 & $\leq 0.05$ & {$\left[\begin{array}{llllllll}2 & 12 & 0 & 3 & 1 & 0 & 0 & 0\end{array}\right]$} & $40,398.00$ & 8507.70 & 6.24 & 23.74 \\
\hline 3 & $\leq 0.1$ & {$\left[\begin{array}{llllllll}3 & 1 & 6 & 3 & 0 & 1 & 0 & 0\end{array}\right]$} & $34,981.00$ & 6868.20 & 5.14 & 25.46 \\
\hline 4 & $\leq 0.15$ & {$\left[\begin{array}{llllllll}0 & 3 & 8 & 0 & 1 & 0 & 0 & 0\end{array}\right]$} & $28,873.00$ & 5991.20 & 4.22 & 25.88 \\
\hline 5 & $\leq 0.20$ & {$\left[\begin{array}{llll}0 & 10 & 1 & 0\end{array}\right]$} & $28,463.00$ & 5413.60 & 3.8 & 26.29 \\
\hline 6 & $\leq 0.25$ & {$\left[\begin{array}{llllllll}2 & 0 & 7 & 1 & 0 & 1 & 0 & 0\end{array}\right]$} & $28,711.00$ & 5252.20 & 3.8 & 27.33 \\
\hline
\end{tabular}


As shown in the graphs 8.3 and 8.4, the LPSP shows the inverse relationship with total system cost and the system size.

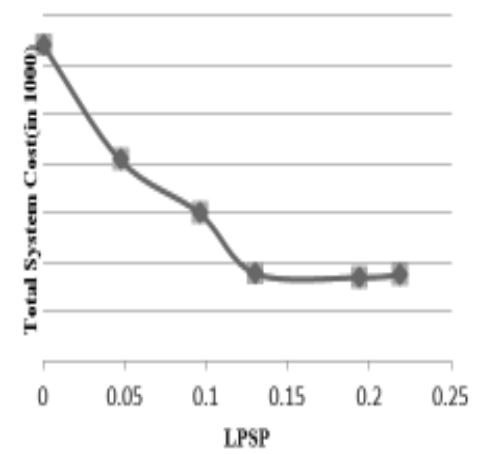

Figure 5: LPSP versus Total System Cost

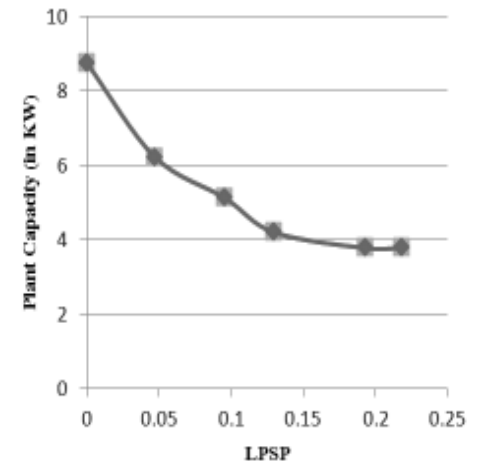

Figure 6: LPSP versus Plant Capacity

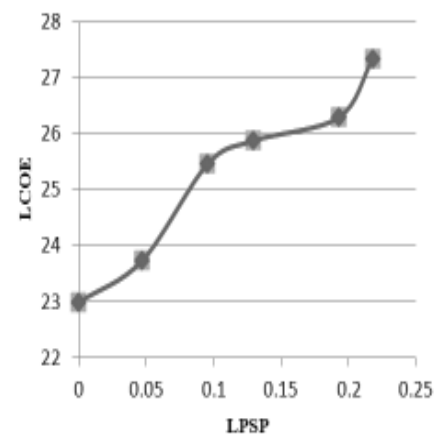

Figure 7: LPSP versus LCOE

But, LCOE decreases with the decrement of LPSP due to increment in System size. The graph as shown above depicts the relationship between LPSP versus LCOE in Figure8.5. The LCOE shows the direct relationship with LPSP.

\subsection{Comparison of Existing System with Proposed System}

The Existing system in Palethar repeater is compared with optimized solution with different LPSP. The result is shown in table 8.2.

Table 3: Comparison of Existing System with Proposed System

\begin{tabular}{|c|l|l|c|c|c|}
\hline S.N. & \multicolumn{1}{|c|}{ Parameters } & $\begin{array}{l}\text { Existing } \\
\text { System }\end{array}$ & $\begin{array}{c}\text { Proposed System } \\
\text { with LPSP=0 }\end{array}$ & $\begin{array}{c}\text { Proposed } \\
\text { System with } \\
\text { LPSP=0.1 }\end{array}$ & $\begin{array}{c}\text { Proposed } \\
\text { System with } \\
\text { LPSP=0.25 }\end{array}$ \\
\hline 1 & $\begin{array}{l}\text { Total System Cost } \\
\text { (in US \$) }\end{array}$ & $24,817.00$ & $52,055.15$ & $34,981.00$ & $28,711.00$ \\
\hline 2 & $\begin{array}{l}\text { Plant Capacity (in } \\
\mathrm{kW})\end{array}$ & 3.06 & 8.76 & 5.14 & 3.8 \\
\hline 3 & LCOE (cents/kWh) & 28.45 & 23 & 25.46 & 27.33 \\
\hline 4 & LPSP & 0.3704 & 0 & 0.0958 & 0.2183 \\
\hline
\end{tabular}

From above table 8.2 it can be seen that the System cost increases by 1.16 times and plant capacity increases by 1.24 times on switching from existing system to proposed system with LPSP of 0.25 . Similarly, the system cost increases by 1.41 times and plant capacity increases by 1.68 times on switching from existing system to proposed system with LPSP of 0.1 . And, both the system cost and the plant capacity increases by 2.10 times and 2.86 times on switching from existing system to the proposed system with LPSP of 0 .

\section{Conclusion}

As the reliability of the system was reflected by LPSP, lower the value of LPSP, higher the reliability. And, for higher reliability, there should be increment of plant capacity which ultimately increases the total system cost. It means that System achieved higher reliability with the increment of cost and plant capacity.But, LCOE decreases with the decrement of LPSP due to increment in System size. 
Since repeater station plays the vital role, its lower reliability i.e. frequency of outage causes the severe revenue loss. For the achievement of higher reliability, the optimization has to be carried out in several repeater stations of Nepal Telecom which are remotely located.

\section{References}

1. K. Awale and N. R. Karki, "Reliability Assessment of Standalone Hybrid Energy System for Remote Telecom Tower," in Proceedings of IOE Graduate Conference, 2015.

2. M. Soursos, C. Protogeropoulos and P. Suuronen, "STAND-ALONE PHOTOVOLTAIC SYSTEMS FOR TELECOMMUNICATION STATIONS IN GREECE," World Conference and Exhibition on Photovoltaic Solar Energy Conversion, 1998.

3. D. Xu, L. Kang, L. Chang and B. Cao, "Optimal sizing of standalone hybrid wind/PV power systems using Genetic Algorithms," IEEE, 2005.

4. W. Dong, Y. Li and J. Xiang, "Optimal sizing of a stand-alone hybrid power system based on Battery/Hydrogen with an Improved Ant Colony Optimization," Energies, 2016.

5. A. Cano, F. Jurado, H. Sanchez and L. M. Fernandez, "Optimal sizing of stand-alone hybrid systems based on PV/WT/FC by using several methodologies," Elsevier, 2014.

6. I. Tegani, M. Becherif, M. Ayad, O. Kraa and O. Akhrif, "Optimal sizing design of stand-alone photovoltaic/wind generator systems using genetic algorithms," ResearchGate, 2015.

7. R. H. Toyama, "Radio Repeater Station," 241 2008. [Online]. Available: http://www2.hawaii.edu/ rtoyama/repeater.html.

8. D. J. Noordhof, "Basic Radio Awareness," 184 2017. [Online]. Available: https://www.taitradioacademy.com/topic/repeater-systems-1/.

9. GoN, CONSTITUTION OF NEPAL 2015, Kathmandu: Constituent Assembly Secretariat, Singhadurbar, 2015.

10. S. Poudel, "Optimization of Hybrid PV/Wind Power System for Remote Telecom Station," Institute of Engineering, Pulchowk Campus, Kathmandu, 2011.

11. R. Belfkira, L. Zhang and G. Barakat, "Optimal sizing study of hybrid wind/PV/diesel power generation unit," ELSEVIER, 2011.

12. L. Zhang, G. Barakat and A. Yassine, "Deterministic Optimization and Cost Analysis of Hybrid PV/Wind/Battery/Diesel Power System," International Journal of Renewable Energy Research, 2012.

13. N. I. A. Aziz, S. I. Sulaiman, S. Shaari and I. Musirin, "Optimal sizing of stand-alone photovoltaic system by minimizing the loss of power supply probability," ELSEVIER, 2017.

14. O. Ekren and B. Y. Ekren, "Size optimization of a PV/wind hybrid energy conversion system with battery storage using simulated annealing," ELSVIER, 2010.

15. J. Page, "The estimation of monthly mean values of daily total short-wave radiation of vertical and inclined surface from sunshine records for latitudes," in New Sources of Energy, 1964.

16. J. Duffie and W. Beckman, Solar Engineering of Thermal Processes, 2005,3rd.

17. D. Larry, "Simulation and Uncertainity: Weather Predictions," in Advanced Bldg Simulation, Newyork and London, Spon Press, 2004, pp. 60-86. 
combinations of PV-Wind-Diesel-Battery hybrid system for telecommunication applications indifferent cities of Punjab, India," Elsevier, 2017.

19. J. Na, Y. Lim and C. Han, "A modified DIRECT algorithm for hidden constraints in an LNG process Optimization," ELSEVIER, 2017.

20. A. Chipperfield, P. Fleming, H. Pohlheim and C. Fronseca, Genetic Algorithm Toolbox User's Guide, Department of Automatic Control and Systems Engineering, University of Sheffield, 1995.

21. L. M. Rios and N. V. Sahinidis, "Derivative-free optimization: a review of algorithms and comparison of software implementations," Springer, 2012.

22. E. Koutroulis, D. Kolokotsa, A. Potirakis and K. Kalaitzakis, "Methodology for optimal sizing of stand-alone photovoltaic/wind-generator systems using genetic algorithms," ELSEVIER, 2006.

23. S. A. G. A. A.H.Shahirinia, "Optimal sizing of hybrid power system using Genetic Algorithm," 2005.

24. E. Lorenzo, "Energy collected and delivered by PV modules," in Handbook of Photovoltaic Science and Engineering, 2003, pp. 905-970.

25. D. Zhao, "Analysis of climate characteristics of sunshine hours in Dalian city in recent 59 years," Anhui Agriculture and Science, pp. 6614-6615,6660, 2011.

26. J. Duffie and C. Smith, "World Distribution of Solar Radiation," University of Wisconsin, Madison, 1966a.

27. B. Liu and R. Jordan, "Solar Energy," The Interrelationship and characteristic distribution of solar radiation, 1960.

28. B. Liu and R. Jordan, "The Longterm average performance of flat plate solar energy collectors," Solar Energy, 1963.

29. MathWorks, "Global Optimization Tool Box," 313 2018. [Online]. Available: https://www.mathworks.com/products/global-optimization.html. [Accessed 8 July 2017].

30. Mathworks, "Genetic Algorithm Solver," 313 2018. [Online]. Available: https://www.mathworks.com/products/global-optimization/features.html\#genetic-algorithmsolver.

31. GoogleMAP, "GoogleMap," 1212 2017. [Online]. Available: https://www.google.com/maps/@29.3715188,80.5999706,11043m/data=!3m1!1e3.

32. Kyocera, "KyoceraSolar," 158 2017. [Online]. Available: https://www.kyocerasolar.com/dealers/product-center/archives/spec-sheets/KC200GT.pdf.

33. YingliSolar, "Yingli," 158 2017. [Online]. Available: http://www.yinglisolar.com/en/products/solar-modules/.

34. SunPower, "SunPower," 158 2017. [Online]. Available: https://us.sunpower.com/homesolar/solar-cell-technology-solutions/.

35. RECSolar, "REC," 109 2017. [Online]. Available: https://www.recgroup.com/en.

36. Narada, "Narada," 2510 2017. [Online]. Available: 
http://en.naradapower.com/index.php/technologies? ctype $=50$.

37. Shuangdeng, "Shoto," 1110 2017. [Online]. Available: http://www.shuangdeng.com.cn/index2.html.

38. SacredSun, "Sacred Sun," 1911 2018. [Online]. Available: http://www.sacredsun.com/productsall.html.

39. Toyo, "Toyo," 1111 2018. [Online]. Available: http://toyobatterymyanmar.com/batterytype/ups-telecom.

40. N. mfd, "Meterological Forecasting Division, Nepal," 251 2018. [Online]. Available: http://www.mfd.gov.np/.

41. Statoids, "Provinces of Nepal," 201712 12. [Online]. Available: http://www.statoids.com/unp.html.

42. F. Power Department, Interviewee, Solar Power Stations of Nepal Telecom in Far-wetern Region. [Interview]. 1792017.

43. G. Masters, Renewable and efficient electric power systems, NJ, USA: John Wiley and Sons Inc., 2013.

44. T. Khatib and A. M. Ibrahim A. Ibrahim, "A review on sizing methodologies of photovoltaic array and storage battery in a standalone photovoltaic system," ELSEVIER, pp. 430-488, 2016.

45. M. Sidrach-de-Cardona and L. M. Lopez, "A simple model for sizing standalone photovoltaic system," Solar Energy Materials and Solar Cells, pp. 199-214, 1998.

46. M. Egido and E. Lorenzo, "The sizing of standalone PV system," Solar Energy Materials and Solar Cells, pp. 51-69, 1992. 